DOI: $10.1515 / \mathrm{rrlm}-2016-0036$

\title{
Genetic polymorphisms of glutathione $S$ transferase and cervical intraepithelial neoplasia
}

\author{
Polimorfismele genice ale glutation S-transferazei \\ și neoplazia intraepitelială de col uterin
}

\begin{abstract}
Mureșan Daniel ${ }^{1, *}$, Andreea Cătană², Radu Anghel Popp ${ }^{2}$, Diana Elena Dumitraș $^{3}$, Florin Stamatian ${ }^{4}$, Anca Dana Buzoianu ${ }^{5}$, Ioana Cristina Rotar ${ }^{4}$

'Department of Mother and the Baby, University of Medicine and Pharmacy "Iuliu Hatieganu”, Cluj Napoca, Romania, ${ }^{2}$ Department of Molecular Sciences, University of Medicine and Pharmacy "Iuliu Hatieganu”, Cluj Napoca, Romania, ${ }^{3}$ Department of Economic Sciences, University of Agricultural Sciences and Veterinary Medicine, Cluj-Napoca, Romania, ${ }^{4} 1^{\text {st }}$ Clinic of Obstetrics and Gynecology, University of Medicine and Pharmacy "Iuliu Hatieganu”, Cluj Napoca, Romania, ${ }^{5}$ Department of Pharmacology, Toxicology and Clinical Pharmacology, University of Medicine and Pharmacy "Iuliu Hatieganu”, Cluj-Napoca, Romania
\end{abstract}

\begin{abstract}
Aim: The present study aim to analyze the relationship between GST M/T genotypes of glutathione S-transferases and cervical intraepithelial neoplasia. Materials and Methods: A prospective case-control study has been designed including 69 cases with different degrees of cervical dysplasia and 107 controls. All patients had been examined colposcopically. For every patient both cervical and blood specimen have been obtained. The peripheral blood was used for GST M/T genotyping. The statistical analysis was performed using OR and chi-square at a level of significance inferior to 0.05 .

Results: No statistically significant differences had been found between cases and controls for GST T-/M- genotype $\left(T-/ M-, \chi^{2}=0.03, p=0.8610\right)$ and $T+/ M+\chi^{2}=0.65, p=0.4197$. Patients with in situ carcinoma had significant GST genotype association for T-/M+ genotype (OR=4.66, CI 95\% [0.6528,24.9725], $\left.\chi^{2}=4.6, p=0.0314\right)$ and for $T+/ M$ - genotype $\left(O R=0.12\right.$, CI 95\% [0.0027,0.9465], $\left.\chi^{2}=0.05, p=0.0219\right)$. Conclusion: The combination of GST genotypes can be included in a predictive score for patients with cervical carcinoma.
\end{abstract}

Keywords: cervical intraepithelial neoplasia, HPV, SNP, GST.

\section{Rezumat}

Obiective: Cercetareaprezentă îșipropunesăanalizezerelațiadintregenotipurile GSTM/TaleglutationS-transferazei și neoplazia intraepitelială intracervicală. Material și metode: A fost realizat un studiu prospectiv de tip caz-martor, ce a inclus 69 paciente cu diferite grade de neoplazie intraepitelială cervicală și 107 controale negative pentru leziuni intraepiteliale. Fiecare pacientă a fost examinat colposcopic obținându-se o probă cervicală. Probele de sânge

* Corresponding author:Mureșan Daniel, Department of Mother and the Baby, University of Medicine and Pharmacy Iuliu Hatieganu, Clinicilor Street 3-5, Cluj Napoca, Romania, e-mail: muresandaniel01@yahoo.com.ro 
obținute au fost utilizate pentru genotiparea GSTM/T. Analiza statistică a fost efectuată utilizând testele OR și Hi-patrat la un prag de semnificație statistică inferior 0.05. Rezultate: La comparația globală caz-martor nu au fost decelate diferențe semnificative statistic pentru genotipul GST T-/M- $\left(T-/ M-, \chi^{2}=0.03, p=0.8610\right)$ și $T+/ M+\left(\chi^{2}=0.65\right.$, $p=0.4197)$. In schimb, în cazul paciențiilor cu carcinom in situ asocierile au fost semnificative: risc crescut genotipul T-/M+ $\left(O R=4.66, C I 95 \%\right.$ [0.6528,24.9725], $\left.\chi^{2}=4.6, p=0.0314\right)$ și respectiv efect protector $\hat{i n}$ cazul genotipului $T+/ M-\left(O R=0.12\right.$, CI 95\% [0.0027,0.9465], $\left.\chi^{2}=0.05, p=0.0219\right)$. Concluzie: Genotipurile GST pot $f i$ incluse intr-un sistem de scor pentru carcinomul cervical.

Cuvinte cheie: neoplazia cervicală intraepitelială, HPV, SNP, GST.

Received: $26^{\text {th }}$ April 2016; Accepted: 26 ${ }^{\text {th }}$ September 2016; Published: 03 ${ }^{\text {th }}$ October 2016.

\section{Introduction}

Cervical neoplasia is the second most prevalent cancer in women after lung cancer, representing one of the major morbidity causes, especially in young women $(1,2)$.

Scientific medical research over the past two decades has brought conclusive and unquestionable evidence that cervical neoplasia results from persistent chronic infections with oncogenic types of the human papilloma virus (HPV) known as high-risk HPV (hrHPV). Virtually, hrHPV DNA is found in all $(99 \%)$ of invasive cervical tumors of the affected women $(3,4)$.

Although the viral etiology of cervical cancer is incontestable, only a part of the HPV infected women develop cancer, so the pathogenesis of this neoplastic event involves potential immune and genetic individual characteristics. The molecular study of HPV carcinogenesis has been a major research topic trying to identify the genetic predisposing factors involved in the etiopathogenesis of cervical cancer (5). There are a number of studies demonstrating that personal genetic particularities are important when defining higher susceptibility to HPV infections and cervical neoplasia, particularly the effect of the viral oncoproteins E6 and E7, the loss of heterozygosity in some chromosomal region, and, last but not least, different polymorphisms of the MHC, p53, immune response and detoxifying genes $(6,7)$. Most of the existing data related to cervical cancer have mainly focused on oncogen- ic HPV strains and other environmental factors, therefore, the role of host genetic susceptibility to cervical carcinogenesis is still largely unknown (8). Previous research has suggested the potential implication of genetic polymorphisms in cancer susceptibility $(8,9)$. Ongoing research related to genetic predisposition upon viral induced malignancy is expected to have a potential impact on prevention strategy and future prognosis $(9,10)$.

The glutathione S-transferases (GSTs) represent an important class of detoxifying enzymes belonging to phase II detoxification enzymes superfamily, which protect cells against endogenous and exogenous molecular injury inducing compounds including mutagens, carcinogens and other toxic chemicals, thus playing a crucial role in the detoxification process (11). The genes for both GSTM1 and GSTT1 isoforms could exhibit an insertion/deletion polymorphism null alleles/ genotypes resulting in loss of enzymatic activity which was associated with a number of malignancies including cervical neoplasia (12-14). Previous reports have associated GST M1 and T1 null genotype with an enhanced risk of precancerous lesions or cervical cancer $(15,16)$, but still, other studies have not confirmed this correlation (12). Considering that null alleles of GSTM1 and GSTT1 genes could be used as potential molecular markers in cervical cancer prevention, further large studies and adequate meta-analyses are needed to confirm and validate this hypothesis.

The present research aims to analyze the potential link between GSTM1 and GSTT1 null 
variants and cervical intraepithelial neoplasia in a group of women from Transylvania, Romania.

\section{Materials and Methods}

\section{Cases and controls}

The present research received the approval of the Ethics Committee of the directing institution (University of Medicine and Pharmacy "Iuliu Hatieganu", Cluj-Napoca, Romania) and was conducted according to the Helsinki Declaration. All subjects included in the current study agreed and signed the written informed consent. The study was cross-sectional.

The study included a total of 176 female subjects (women of Romanian and Hungarian ethnicity, all Caucasians), of whom 69 cases and 107 healthy volunteers, and was performed in the $1^{\text {st }}$ Obstetrics and Gynecology Clinic of Cluj-Napoca, Romania between $1^{\text {st }}$ of January 2014-30 ${ }^{\text {th }}$ of June 2014.

Every patient was scheduled for two visits. During the first visit, a physical examination was performed, followed by cervical probe collection. Cervical probes were used for cervical cytology classification according to the Bethesda system (17) and HPV testing. The HPV testing was performed in a qualitative manner using an immunohistological test that could detect the presence of HPV strains (Viroaktiv from Virofem $^{\circledR}$ ). During the second visit, colposcopy was performed. At the end of the visit $2 \mathrm{~mL}$ of peripheral blood were drawn and stored at $4{ }^{\circ} \mathrm{C}$ for subsequent DNA extraction.

Controls were represented by cytological negative for intraepithelial neoplasia (NILM) patients according to the Bethesda terminology, negative for HPV testing and also with a normal colposcopy.

The group of cases was represented by patients with abnormal Pap smear results and positive for hrHPV. The colposcopy was performed according to 2011 colposcopic terminology of the International Federation for Cervical Pathology and Colposcopy (18). Colposcopy was used to choose the most appropriate site of biopsy. The results of the biopsy allowed the classification of cases into the following histological categories: in situ carcinoma (CIS), high grade intraepithelial lesions (HSIL), and low grade intraepithelial lesion (LSIL). No case of invasive carcinoma was recorded in the study group. The histological classification of cervical dysplasia was based on ASCCP 2012 terminology (American Society for Colposcopy and Cervical Pathology - ASCCP) (19). Patients with abnormal Pap smears results but negative for hrHPV were not included in the study.

\section{Molecular analysis of null alleles of GSTM1 and GSTT1 genes}

Genotyping for M1 and T1 alleles of GST gene was performed by Multiplex PCR using a protocol previously described by Bid HK (20). Although the current protocol does not allow discriminating between GSTM1 and GSTT1 homozygous and heterozygous genotypes, 4 different genotypes were identified and used for further statistical analysis: GSTM1 wild type or positive normal M1 allele $(\mathrm{M} 1+)$, GSTT1 wild type or positive T1 allele $(\mathrm{T}+)$, GSTM1 variant or null allele (M1-), GSTT1 variant or null allele (T1-).

\section{Statistical analysis}

GSTM1 and GSTT1 polymorphism genotype distribution between different cytological groups was compared using Fisher's exact test. For estimation of the relationship between the odds ratio (OR) of different cytological classes was used at 95\% confidence interval (CI). The risk associated with each genotype was assessed by logistic regression analysis. P-value under 0.05 was assumed statistically significant. STATA Intercooled 10 (College Station, Texas, USA) and SPSS 18.0 for Windows were used for statistical calculations (SPSS, Inc, Chicago, Il., USA). 


\section{Results}

The average mean age of patients was 39.30 years, 42.49 years in the control group, respectively, with no statistical significant differences $(p=0.258)$. Enrolled patients were classified in specific subgroups according to 2012 ASCCP Consensus Guidelines (19). The largest category was represented by high grade disease and in situ carcinoma $43.48 \%$.

While comparing cases versus controls, no link was found between cervical intraepitheli-

Table 1. GST M1/T1 genotype analysis

\begin{tabular}{|c|c|c|c|c|}
\hline Comparison & OR & OR 95\% CI & Chi-squared & $\mathbf{p}$ \\
\hline \multicolumn{5}{|l|}{$T-/ M$} \\
\hline cases/controls & 1.0846 & {$[0.3836,2.9348]$} & 0.03 & 0.8610 \\
\hline LSIL/controls & - & - & - & - \\
\hline HSIL/controls & 0.8034 & {$[0.814,4.0543]$} & 0.07 & 0.7845 \\
\hline $\begin{array}{l}\text { LSIL+HSIL+CIS/ } \\
\text { controls }\end{array}$ & 0.6573 & {$[0.1134,2.6138]$} & 0.39 & 0.5298 \\
\hline CIS/controls & 0.8034 & {$[0.0170,6.7155]$} & 0.04 & 0.8413 \\
\hline HSIL+CIS/controls & 0.7747 & {$[0.1325,3.1138]$} & 0.14 & 0.7050 \\
\hline \multicolumn{5}{|l|}{$T-/ M+$} \\
\hline cases/controls & 1.166 & {$[0.1902,5.0958]$} & 0.05 & 0.8256 \\
\hline LSIL/controls & 7.2592 & {$[0.5234,70.2258]$} & 5.38 & 0.0203 \\
\hline HSIL/controls & 0 & {$[0,2.1848]$} & 1.81 & 0.1784 \\
\hline CIS/controls & 4.6666 & {$[0.6528,24.9725]$} & 4.63 & 0.0314 \\
\hline $\begin{array}{l}\text { LSIL+HSIL+CIS/ } \\
\text { controls }\end{array}$ & 1.7562 & {$[0.4274,6.3411]$} & 0.92 & 0.3387 \\
\hline HSIL+CIS/controls & 1.1666 & {$[0.1902,5.0958]$} & 0.05 & 0.8256 \\
\hline \multicolumn{5}{|l|}{$T+/ M-$} \\
\hline cases/controls & 1.2982 & {$[0.6533,2.5654]$} & 0.65 & 0.4197 \\
\hline LSIL/controls & - & - & - & - \\
\hline HSIL/controls & 1.0980 & {$[0.3755,3.2072]$} & 0.04 & 0.8478 \\
\hline CIS/controls & 0.1220 & {$[0.0027,0.9465]$} & 5.25 & 0.0219 \\
\hline LSIL+HSIL+CIS/controls & 0.4831 & {$[0.8222,4.4447]$} & 2.80 & 0.0942 \\
\hline HSIL+CIS/controls & 0.6039 & {$[0.2376,1.4801]$} & 1.44 & 0.2300 \\
\hline \multicolumn{5}{|l|}{$T+M+$} \\
\hline cases/controls & 1.2982 & {$[0.6533,4.0543]$} & 0.07 & 0.7845 \\
\hline LSIL/controls & 3.2205 & {$[0.3480,39.76]$} & 1.72 & 0.1897 \\
\hline HSIL/controls & 1.4313 & {$[0.4606,4.2162]$} & 0.51 & 0.4730 \\
\hline CIS/controls & 2.1470 & {$[0.4576,9.9428]$} & 1.37 & 0.2424 \\
\hline LSIL+HSIL+CIS/controls & 1.9221 & {$[0.8222,4.4447]$} & 2.80 & 0.0942 \\
\hline HSIL+CIS/controls & 1.7681 & {$[0.7138,4.3082]$} & 1.90 & 0.1682 \\
\hline
\end{tabular}


al neoplasia and GST M1 and GST T1 genetic polymorphisms (T-/M-, $\chi^{2}=0.03, \mathrm{p}=0.8610$; $\mathrm{T}-/ \mathrm{M}+, \chi^{2}=0.15, \mathrm{p}=0.6961 ; \mathrm{T}+/ \mathrm{M}-, \chi^{2}=1.24$, $\left.\mathrm{p}=0.2659 ; \mathrm{T}+/ \mathrm{M}+\chi^{2}=0.65, \mathrm{p}=0.4197\right)$. The complete analysis of GST M1 and T1 genotypes is presented in table I. Instead of a more subtle analysis on subgroup of cervical intraepithelial neoplasia (CIN), significant findings were noted.

The combination of GST T-/M+ genotype represents a significant risk factor for LSIL and CIS (OR=7.2592, $\mathrm{p}=0.0203$, and $\mathrm{OR}=4.6666$, $\mathrm{p}=0.0314$, respectively). On the other hand, the $\mathrm{T}+\mathrm{M}$ - genotype combination seems to exert a protective effect in patients with CIS $(\mathrm{OR}=0.1220, \mathrm{p}=0.0219)$. The effect of genotypes was confirmed by the logistic regression analy- sis, where each cytological class was considered as dependent variable and the two genotypes as independent variables (table II). The results of logistic regression were concordant with previous analysis: significant increased risk for GST $\mathrm{T}-\mathrm{M}+$ for LSIL $(\mathrm{OR}=7.259$, [1.069; 49.268], $\mathrm{p}=0.042)$ and CIS (OR=4.667, [1.026-21.231, $\mathrm{p}=0.046]$, and significant decreased risk for developing CIS in case of GST T+/M- $(\mathrm{OR}=0.122$, [0.015;0.997], $\mathrm{p}=0.05]$.

\section{Discussion}

Worldwide, cervical cancer remains the second most common cause of neoplasia related deaths in women. Persistent hrHPV cervical infections represent the most important contributing factor

Table 2. Effect genotypes by logistic regression analysis

\begin{tabular}{|c|c|c|c|c|}
\hline & Genotype & OR & $95 \% \mathrm{CI}$ & $\mathbf{p}$ \\
\hline \multicolumn{5}{|l|}{ LSIL } \\
\hline LSIL\# & GST T-/M- & - & & \\
\hline LSIL & GST T-/M+ & 7.259 & $1.069-49.268$ & 0.042 \\
\hline LSIL\# & GST T+/M- & - & & \\
\hline LSIL & GST T+/M+ & 3.220 & $0.514-20.175$ & 0.212 \\
\hline \multicolumn{5}{|l|}{ HSIL } \\
\hline HSIL & GST T-/M- & 0.803 & $0.167-3.868$ & 0.785 \\
\hline HSIL\# & GST T-/M+ & - & & \\
\hline HSIL & GST T+/M- & 1.098 & $0.422-2.853$ & 0.848 \\
\hline HSIL & GST T+/M+ & 1.431 & $0.536-3.824$ & 0.474 \\
\hline \multicolumn{5}{|l|}{$C I S$} \\
\hline CIS & GST T-/M- & 0.803 & 0.0940-6.869 & 0.842 \\
\hline CIS & GST T-/M+ & 4.667 & $1.026-21.231$ & 0.046 \\
\hline CIS & GST T+/M- & 0.122 & $0.015-0.997$ & 0.050 \\
\hline CIS & GST T+/M+ & 2.147 & $0.582-7.915$ & 0.251 \\
\hline \multicolumn{5}{|l|}{$L S I L+H S I L+C I S$} \\
\hline LSIL+HSIL+CIS & GST T-/M- & 0.678 & $0.181-2.532$ & 0.563 \\
\hline LSIL+HSIL+CIS & GST T-/M+ & 1.814 & $0.565-5.831$ & 0.317 \\
\hline LSIL+HSIL+CIS & GST T+/M- & 0.503 & $0.224-1.129$ & 0.096 \\
\hline LSIL+HSIL+CIS & GST T+/M+ & 1.808 & $0.829-3.943$ & 0.137 \\
\hline
\end{tabular}


in its etiology and progression $(21,22)$. Infections with hrHPV could evolve in inducing or transforming cervical intraepithelial neoplasia lesions (23). In patients with HSIL lesions, hrH$\mathrm{PV}$ are found integrated in the cell nucleus in socalled transformed infections $(23,24)$. In high grade lesions with persistent oncogenic HPV, molecular anomalies in host cell genome accumulate gradually, underlying the prior characteristic progression to cancer (24). Although hrHPV infections represent undoubtedly the major risk factor for cervical cancer, a broad array of individual genetic variants that accompany HPV infections in different stages of preneoplastic events and promotion to cervical cancer have been identified in recent decades. These data are strongly supported by epidemiological studies $(25,26)$.

Different genetic polymorphisms might be related to HPV persistence and progression to cancer, some of them related to cervical cancer $(25,26)$. Among these, genetic polymorphisms of GST genes were intensely studied in relationship to chronic hrHPV infections and cervical cancer, but results are still inconclusive even if large populations with different ethnicities were included $(27,28)$. GST polymorphisms have been previously analyzed in study lots from Transylvania in relationship with other pathologies such as glaucoma and lung cancer $(29,30)$.

The persistent HPV HR infections are asymptomatic, but can determine low grade, high grade lesions, in situ carcinoma, or cervical cancer. Since it is very difficult to realize a longitudinal study that might include patients without any cytological anomalies for decades in order to see the relationship between GST M1 and T1 genetic polymorphisms and HPV HR infections, the present study has included HPV-HR positive patients with LSIL, HSIL or in situ carcinoma, which, accordingly to the known HPV natural history $(1,2,4,5,22,23)$, are due to persistent
HPV-HR that cause significant squamous cell modifications.

A meta-analysis, including a total of 15 case-control studies comprising 1825 cases and 2104 controls, provides well-founded evidence that the GSTM1 null genotype is correlated with the development of cervical neoplasia, especially in Indian and Chinese populations. In the same meta-analysis, smoking is linked between GSTM1 null genotype and cervical cancer (27). In contrast, other studies show that polymorphisms in GSTM1 and GSTT1 genes are not associated with a higher risk for cervical cancer in HPV infected women $(16,28)$. In our study, the GST M1 null genotype was a significant protecting factor for CIS (OR $=0.1220, \chi^{2}=5.25$, $\mathrm{p}=0.0219)$, while GST T-/M+ genotype was associated with a significantly increased risk for developing LSIL and CIS (OR=7.2592, $\mathrm{p}=0.0203$, and $\mathrm{OR}=4.6666, \mathrm{p}=0.0314$, respectively).

As most of the current data refer to Asian populations, previous studies focused on Caucasian populations in order to identify possible ethnic differences for GST polymorphism distribution and their relationship with cervical cancer. The results of a study that included 253 women with a persistent high-risk HPV positivity showed a significant association of GSTM1 and GSTT1 null genotypes with cervical dysplasia in Caucasians (31). Hence, null GSTM1 and GSTT1 genotypes should both be counted in the risk assessment algorithms of Caucasian individuals as well in Asian ones (31).

To the best of our knowledge, the current comparative analysis of GSTM1 and GSTT1 variants in patients diagnosed with cervical intraepithelial neoplasia is the first one in Eastern Europe, and therefore, also in Romania. All subjects enrolled in the study were Caucasians. The study group, from a strictly statistical point of view, cannot be considered population representative, the estimation of the exact number of 
cases being difficult due to the unknown prevalence of cervical dysplasia in Transylvania. The relatively small number of enrolled patients is a limitation of the present study, but this research is conclusive from a statistical point of view and the results encourage more complex future studies. Overall, null genotypes of GSTM1 and GSTT1 genes are not associated with cervical cancer and precancerous lesions. The results are concordant with other previous studies $(32,33)$.

In contrast, $\mathrm{T}-\mathrm{M}+$ genotype was associated with a significant higher risk for $\operatorname{LSIL}(\mathrm{OR}=7.25$, chi-square $=5.38, \mathrm{p}=0.0203)$ and CIS $(\mathrm{OR}=4.66$, chi-square $=4.63, \mathrm{p}=0.0314$ ). Also, a significant association has been found between $\mathrm{T}+/ \mathrm{M}-$ genotype and CIS ( $\mathrm{OR}=0.1220$, chi-square $=5.25$, $\mathrm{p}=0.0219)$. The results are conflicting at first sight, but we have to bear in mind that GSTs play an important role in cell detoxification and that it is impossible to assess all the potential co-carcinogens. Among them, tobacco smoking represents a well-known cofactor for cervical cancer; the risk of developing a CIN2+ lesion is higher among women who smoke with abnormal Pap smears (34). Moreover, GSTs are involved in major detoxification pathways (35).

One of the limitations of the present study is that it does not evaluate GST polymorphisms in relationship with other associated risk factors involved in cervical neoplasia. All meta-analyses and multicentric reports highlight that smoking is an important environmental carcinogenic cofactor for cervical neoplasia (36-39). A study taking into account 150 smoking women diagnosed with cervical neoplasia showed significant association with an increased risk of 4.19-folds of developing cervical cancer in association of GSTM1 null genotypes (40). Other studies confirm that there is a positive association between active or passive smoking, GST null genotypes and the risk of developing cervical cancer $(27,28)$.
A seven-year follow-up study of patients with persistent high-risk HPV infections shows that they are more likely to develop a high grade disease in the presence of GSTM1 and GSTT1 null genotype (40).

It is known that GSTT- allele alone, or the combined GSTT-/GSTM- genotype is considered a risk factor for cancer in general and also for cervical cancer (41). In the present study, the double null genotype was not significantly associated with any category of cervical dysplasia.

Although the enzymatic deficiency due to GSTM null genotype is considered a risk factor in cervical neoplasia, the $\mathrm{T}+/ \mathrm{M}$ - genotype seems to exert an inverse statistical relationship, if not a protective effect, in a patient with CIS in our study $(\mathrm{OR}=0.1220$, chi-square $=5.25, \mathrm{p}=0.0219)$.

The continuous and particular interest in the molecular influences of GST detoxifying enzymes and their impact on the onset and progression of cancer could explain the pathogeny of the disorder, on the one hand, and could influence the response to therapy on the other. As only a part of the HPV infected women develop precancerous cervical lesions or cancer, prophylactic evaluation of GST family enzymes could play a major role in identifying high risk individuals for an efficient therapeutic interference, here including HPV vaccination $(42,43)$.

Our data support the inclusion of GST M/T genotypes in a potential predictive score system for cervical intraepithelial neoplasia.
Abbreviations
bp = base pairs
CI = confidence interval
CIS = in situ carcinoma
GSTs = Glutathione S-transferases
$\mathrm{HPV}=$ human papillomavirus
hrHPV = high risk HPV
HSIL = high grade intraepithelial lesion 


$\begin{aligned} \text { LSIL = } & \text { Low grade intraepithelial lesion } \\ \mathrm{MHC}= & \text { major histocompatibility complex } \\ \mathrm{M}- & =\text { null homozygous GST-M1 } \\ & \text { (variant) genotype } \\ \mathrm{M}+\quad & \text { heterozygous or homozygous } \\ & \text { GST-M1 wild genotype } \\ \mathrm{T}- & \text { null homozygous GST T1 (variant) } \\ & \text { genotype } \\ = & \text { heterozygous or homozygous } \\ & \text { GST-T1 wild genotype }\end{aligned}$

\section{References}

1. Faridi R, Zahra A, Khan K, Idrees M. Oncogenic potential of Human Papillomavirus (HPV) and its relation with cervical cancer. Virol J. 2011 Jun;8:269. DOI: $10.1186 / 1743-422 X-8-269$.

2. Stanley MA. Pathology and epidemiology of HPV infection in females. Gynecol Oncol. 2010 May;117(2 Suppl):S5-10. DOI: 10.1016/j.ygyno.2010.01.024

3. Parkin D. The global health burden of infection associated cancers in the year 2002. Int J Cancer. 2006 Jun;118(12):3030-44. DOI: 10.1002/ijc.21731.

4. Ibeanu OA. Molecular pathogenesis of cervical cancer. Cancer Biology \& Therapy Cancer Biol Ther. 2011 Feb;11(3):295-306. DOI: 10.4161/cbt.11.3.14686.

5. Fernandes JV, Araújo JMG, Fernandes TAAM. Biology and natural history of human papillomavirus infection. Open Access Journal of Clinical Trials.2013;5:1-12. DOI: $10.2147 /$ OAJCT.S37741.

6. Yugawa T, Kiyono T. Molecular mechanisms of cervical carcinogenesis by high-risk human papillomaviruses: novel functions of E6 and E7 oncoproteins. Rev Med Virol. 2009 Mar;19(2):97-113. DOI: 10.1002/rmv.605.

7. Habbous S, Pang V, Eng L, Xu W, Kurtz G, Liu FF, et al. p53 Arg72Pro polymorphism, HPV status and initiation, progression, and development of cervical cancer: a systematic review and meta-analysis. Clin Cancer Res. 2012 Dec;18(23):6407-15. DOI: 10.1158/10780432.CCR-12-1983.

8. Nunobiki O, Ueda M, Toji E, Yamamoto M, Akashi $\mathrm{K}$, Sato N, et al. Genetic Polymorphism of Cancer Susceptibility Genes and HPV Infection in Cervical Carcinogenesis. Patholog Res Int. 2011;2011:364069. DOI: $10.4061 / 2011 / 364069$.
9. Tsigris C, Chatzitheofylaktou A, Xiromeritis C, Nikiteas N, Yannopoulos A. Genetic association studies in digestive system malignancies. Anticancer Res. 2007 Sep-Oct;27(5B):3577-87.

10. Moore EE, Wark JD, Hopper JL, Erbas B, Garland SM. The roles of genetic and environmental factors on risk of cervical cancer: a review of classical twin studies. Twin Res Hum Genet. 2012 Feb;15(1):79-86. DOI: 10.1375/twin.15.1.79.

11. Ueda M, Hung YC, Terai Y, Kanda K, Takehara M, Yamashita H, et al. Glutathione S-transferase GSTM1, GSTT1 and p53 codon 72 polymorphisms in human tumor cells. Hum Cell. 2003 Dec;16(4):241-51. DOI: 10.1111/j.1749-0774.2003.tb00158.x.

12. Wang D, Wang B, Zhai JX, Liu DW, Sun GG. Glutathione S-transferase M1 and T1 polymorphisms and cervical cancer risk: a meta-analysis. Neoplasma. 2011;58(4):352-9. DOI: 10.4149/neo_2011_04_352.

13. Zhen S, Hu C-M, Bian L-H. Glutathione S-Transferase Polymorphism Interactions with Smoking Status and HPV Infection in Cervical Cancer Risk: An Evidence-Based Meta-Analysis. PLoS One. 2013 Dec 31;8(12):e83497. DOI: 10.1371/journal. pone. 0083497 .

14. de Carvalho CR, Silva ID, Pereira JS, de Souza CN, Focchi GR, Ribalta JC. Polymorphisms of p53, GSTM1 and GSTT1, and HPV in uterine cervix adenocarcinoma. Eur J Gynaecol Oncol. 2008;29(6):590-3.

15. Ueda M, Hung YC, Terai Y, Kanda K, Takehara M, Yamashita $\mathrm{H}$ et al. Glutathione S-transferase GSTM1, GSTT1 and p53 codon 72 polymorphisms in human tumor cells. Hum Cell. 2003 Dec;16(4):241-51. DOI: 10.1111/j.1749-0774.2003.tb00158.x.

16. Economopoulos KP, Choussein S, Vlahos NF, Sergentanis TN. GSTM1 polymorphism, GSTT1 polymorphism, and cervical cancer risk: a meta-analysis. Int J Gynecol Cancer. 2010 Dec;20(9):1576-80.

17. Solomon D, Davey D, Kurman R, Moriarty A, O'Connor D, Prey M, et al. The 2001 Bethesda System: terminology for reporting results of cervical cytology. JAMA. 2002 Apr 24;287(16):2114-9. DOI: 10.1001/ jama.287.16.2114.

18. Bornstein J, Bentley J, Bösze P, Girardi F, Haefner H, Menton M, et al. 2011 colposcopic terminology of the International Federation for Cervical Pathology and Colposcopy.Obstet Gynecol. 2012 Jul;120(1):166-72. DOI: 10.1097/AOG.0b013e318254f90c. 
19. Darragh TM, Colgan TJ, Cox JT, Heller DS, Henry MR, Luff RD, et al; Members of LAST Project Work Groups. The Lower Anogenital Squamous Terminology Standardization Project for HPVAssociated Lesions: background and consensus recommendations from the College of American Pathologists and the American Society for Colposcopy and Cervical Pathology. J Low Genit Tract Dis. 2012 Jul;16(3):205-42. DOI: 10.1097/ LGT.0b013e31825c31dd.

20. Bid HK, Konwar R, Saxena M, Chaudhari P, Agrawal CG, Banerjee M. Association of glutathione S-transferase (GSTM1, T1 and P1) gene polymorphisms with type 2 diabetes mellitus in north Indian population. J Postgrad Med. 2010 Jul-Sep;56(3):176-81. DOI: 10.4103/0022-3859.68633.

21. Peralta-Zaragoza O, Bermúdez-Morales VH, PérezPlasencia C, Salazar-León J, Gómez-Cerón C, MadridMarina V. Targeted treatments for cervical cancer: a review. Onco Targets Ther. 2012;5:315-28. DOI: 10.2147/OTT.S25123.

22. Walboomers JM, Jacobs MV, Manos MM, Bosch FX, Kummer JA, Shah KV, et al. Human papillomavirus is a necessary cause of invasive cervical cancer worldwide. J Pathol. 1999 Sep;189(1):12-9. DOI: 10.1002/(SICI)1096-9896(199909)189:1<12::AIDPATH431>3.0.CO;2-F.

23. Woodman CB, Collins SI, Young LS. The natural history of cervical HPV infection: unresolved issues. Nat Rev Cancer. 2007 Jan;7(1):11-22. DOI: 10.1038/ nrc2050.

24. de Sanjose S, Quint WG, Alemany L, Geraets DT, Klaustermeier JE, Tous S, et al: Retrospective International Survey and HPV Time Trends Study Group: Human papillomavirus genotype attribution in invasive cervical cancer: a retrospective cross-sectional worldwide study. Lancet Oncol. 2010 Nov;11(11):1048-56. DOI: $10.1016 / \mathrm{S} 1470-$ 2045(10)70230-8.

25. Chattopadhyay K. A comprehensive review on host genetic susceptibility to human papillomavirus infection and progression to cervical cancer. Indian J Hum Genet. 2011 Sep;17(3):132-44. DOI: 10.4103/09716866.92087.

26. Zoodsma M, Sijmons RH, de Vries EG, Zee AG. Familial cervical cancer: case reports, review and clinical implications. Hered Cancer Clin Pract. 2004 May 15;2(2):99-105. DOI: 10.1186/1897-4287-2-2-99.
27. Liu Y, Xu LZ. Meta-analysis of association between GSTM1 gene polymorphism and cervical cancer. Asian Pac J Trop Med. 2012 Jun;5(6):480-4. DOI: 10.1016/ S1995-7645(12)60083-2.

28. Kiran B, Karkucak M, Ozan H, Yakut T, Ozerkan K, Sag S, et al. GST (GSTM1, GSTT1, and GSTP1) polymorphisms in the genetic susceptibility of Turkish patients to cervical cancer. J Gynecol Oncol. 2010 Sep;21(3):169-73. DOI: 10.3802/jgo.2010.21.3.169.

29. Ster AM, Petrisor FM, Stan C, Pop VI. Gluthathion S-transferase M1 and T1 polymorpisms in a group of Romanian glaucoma patients. Rev Romana Med Lab. 2015;23(4):506-10. DOI: 10.1515/rrlm-2015-0048.

30. Catana A, Popp R, Pop M, Porojan M, Pop V, Trifa A, Petrisor F, Farcas M. Genetic polymorphism of alpha 1 antytrypsin and glutathione $\mathrm{S}$ transferase and lung cancer risk. European Respiratory Journal 2011 38: p1966.

31. Cseh J, Pazsit E, Orsos Z, Marek E, Huszar A, Balogh S, et al. Effect of Glutathione-S-Transferase M1 and T1 Allelic Polymorphisms on HPV-induced Cervical Precancer Formation. Anticancer Res. 2011 Sep;31(9):3051-5.

32. Goodman MT, McDuffie K, Hernandez B, Bertram CC, Wilkens LR, Guo C, et al. CYP1A1, GSTM1, and GSTT1 polymorphisms and the risk of cervical squamous intraepithelial lesions in a multiethnic population. Gynecol Oncol. 2001 May;81(2):263-9. DOI: 10.1006/gyno.2001.6154.

33. Gao LB, Pan XM, Li LJ, Liang WB, Bai P, Rao L, et al. Null genotypes of GSTM1 and GSTT1 contribute to risk of cervical neoplasia: an evidence-based meta-analysis. PLoS One. 2011;6(5):e20157. DOI: 10.1371/journal.pone.0020157.

34. McIntyre-Seltman K, Castle PE, Guido R, Schiffman M, Wheeler CM. Smoking is a risk factor for cervical intraepithelial neoplasia grade 3 among oncogenic human papillomavirus DNA-positive women with equivocal or mildly abnormal cytology. Cancer Epidemiol Biomarkers Prev. 2005 May;14(5):1165-70. DOI: 10.1158/1055-9965.EPI-04-0918.

35. Sheehan D, Meade G, Foley VM, Dowd CA. Structure, function and evolution of glutathione transferases: implications for classification of non-mammalian members of an ancient enzyme superfamily. Biochem J. 2001 Nov;360(Pt 1):1-16. DOI: 10.1042/bj3600001.

36. Fonseca-Moutinho JA. Smoking and Cervical Cancer. ISRN Obstet Gynecol. 2011;2011:847684. DOI: 10.5402/2011/847684. 
37. Collins S, Rollason TP, Young LS, Woodman CBJ. Cigarette smoking is an independent risk factor for cervical intraepithelial neoplasia in young women: a longitudinal study. Eur J Cancer. 2010 Jan;46(2):405-11. DOI: 10.1016/j.ejca.2009.09.015.

38. Byrne MM, Davila EP, Zhao W, Parker D, Hooper MW, Caban-Martinez A, et al. Cancer screening behaviors among smokers and non-smokers. Cancer Epidemiol. 2010 Oct;34(5):611-7. DOI: 10.1016/j. canep.2010.06.017.

39. Louie KS, Castellsague $\mathrm{X}$, de Sanjose S, Herrero R, Meijer CJ, Shah K, et al. Smoking and passive smoking in cervical cancer risk: pooled analysis of couples from the IARC multicentric case-control studies. Cancer Epidemiol Biomarkers Prev. 2011 Jul;20(7):1379-90. DOI: 10.1158/1055-9965.EPI-11-0284.

40. Abbas M, Srivastava K, Imran M, Banerjee M. Association of Glutathione S-transferase (GSTM1, GSTT1 and GSTP1) polymorphisms and passive smoking in cervical cancer cases from North India. Int J Biomed Res. 2013;4:655-62. DOI: 10.7439/ijbr. v4i12.396.
41. Sui Y, Han W, Yang Z, Jiang M. Association of glutathione S-transferase M1 and T1 null polymorphisms with the development of cervical lesions: a meta-analysis. Eur J Obstet Gynecol Reprod Biol. 2011 Dec;159(2):443-8. DOI: 10.1016/j.ejogrb.2011.09.012.

42. Rodríguez M, Mejia F,Lecourtois M, Domínguez V, Castillo J. Influence of GSTT1, GSTM1 and GSTP1 Polymorphisms on the Development of Breast Cancer. J Cancer Ther. 2014;5:552-9. DOI: 10.4236/ jet.2014.56063.

43. Oliveira AL, Rodrigues FF, Santos RE, Aoki T, Rocha MN, Longui CA, et al. GSTT1, GSTM1, and GSTP1 polymorphisms and chemotherapy response in locally advanced breast cancer. Genet Mol Res. 2010 Jun 11;9(2):1045-53. DOI: 10.4238/vo19-2gmr726. 